Int. J. Dev. Biol. 51: 429-438 (2007)

doi: $10.1387 / \mathrm{ijdb} .072390 \mathrm{fg}$

\title{
The molecular biology of ear development - "Twenty years are nothing"\#
}

\author{
FERNANDO GIRALDEZ*,1 and BERND FRITZSCH ${ }^{2}$ \\ ${ }^{1}$ Departament de Ciències Experimentals i de la Salut, Universitat Pompeu Fabra, Parc de Recerca Biomèdica de Barcelona (PRBB), \\ Barcelona, Spain and ${ }^{2}$ Creighton University, Department of Biomedical Sciences, Omaha, NE, USA
}

\begin{abstract}
Views of classical biological problems changed dramatically with the rise of molecular biology as a common framework. It was indeed the new language of life sciences. Molecular biology increasingly moved us towards a unified view of developmental genetics as ideas and techniques were imported to vertebrates from other biological systems where genetics was in a more advanced state. The ultimate advance has been the ability to actually perform genetic manipulations in vertebrate organisms that were almost unthinkable before. During the last two decades these technical advances entered into and affected the research on ear development. These events are still very recent and have been with us for no longer than two decades, which is the reason for the title of this article. This new scenario forms the basis of the current and productive work of many laboratories, and this is what this Special Issue of The International Journal of Developmental Biology wants to show, presenting a snapshot of insights at the beginning of the 21st Century. In this article, we give an overview of the topics that are addressed in this Ear Development Special Issue, and also we take the opportunity to informally dig into the genealogy of some of those topics, trying to link the current work with some classical work of the past.
\end{abstract}

KEY WORDS: cell fate, patterning, hair cell, otic neuron, morphogenesis, evolution, regeneration

\begin{abstract}
Each time is characterised by the field of possibility that defines not only the standing theories or beliefs, but also the nature of the objects which are accessible to analysis, the means to look at them and the way to observe and to talk about them. (Jacob, 1976)
\end{abstract}

There has been a sustained interest in ear developmental biology all throughout the $20^{\text {th }}$ century. As with many other fields in biology and neurosciences, this interest is in part rooted in curiosity and in part is driven by the intent to understand and cure diseases. There is an immense catalogue of histological observations and clever experimental manipulations of the embryonic ear that have contributed to an increase in our knowledge of the development of the ear and that was able to paint a picture of ear development by the end of the eighties (see Rubel, 1978; and the report of the Holte Symposium (Cremers et al., 1987). The view at the end of the eighties, however detailed, remained descriptive and phenomenological: the gap between cells, genes and proteins was still too large and many processes were unknown leaving "the widest gap to be filled... to understanding how cells with identica genomes may become differentiated“ (Jacob, 1947). Thirty years elapsed from the publishing of the double helix in 1953 to the polymerase chain reaction (Saiki et al., 1985) and during this period of time the whole of biology was changed and set a new paradigm. Views of classical biological problems, changed dramatically with the rise of molecular biology as a common framework. It was indeed the new language of life sciences. Molecular biology increasingly moved us towards a unified view of developmental genetics as ideas and techniques were imported to vertebrates from other biological systems where genetics was in a more advanced state. There is no need to stress the enormous effect of Drosophila molecular biology for the understanding of vertebrate development. The ultimate advance has been the ability to actually perform genetic manipulations in vertebrate organisms that were almost unthinkable before. Perhaps one of best examples of that is the discovery of the vertebrate Hox genes based on their homology to fly sequences and the production of

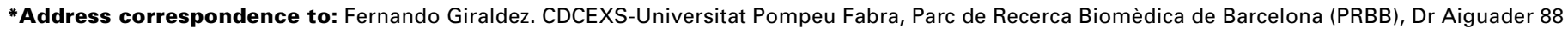
08003-Barcelona, Spain. e-mail: fernando.giraldez@upf.edu
}

\# Note: Refers to an Argentinian tango by Carlos Gardel (1890-1935). 
knockout mice in the late eighties and early nineties (McGinnis W. et al., 1984; Chisaka and Capecchi, 1991). During the last two decades these technical advances entered into and affected the research on ear development, allowing classical problems that have preoccupied developmental biologists for almost 100 years to be rephrased.

All these events are still very recent and have been with us for no longer than two decades, which is the reason for the title of this article. How these new times were viewed at the end of the nineties can be grasped in the reviews by Donna Fekete (Fekete, 1996), Torres and Giraldez (1998) and Fritzsch et al., 1998). Research in molecular aspects of ear related diseases was greatly enhanced in the USA through the formation of a new NIH institute, the NIDCD, in 1988, contributing significantly to the enormous growth in knowledge to molecular and genetic understanding of development over the last 20 years. This new scenario forms the basis of the current and productive work of many laboratories and this is what this special issue of the International Journal of Developmental Biology wants to show, presenting a snapshot of insights at the beginning of the $21^{\text {st }}$ Century. We are fascinated with what we have begun to understand in only a couple of years, although we know that we are at the very beginning of revealing the intricate orchestration of gene expression leading to ear development. The extent of factual knowledge that has been generated during the last ten years is immense, as is the rate at which new genes and molecular networks are brought into the game. In this foreword article, we give an overview of the topics that are addressed in this Ear Development Special Issue and also we take the opportunity to informally dig into the genealogy of some of those topics trying to link the current work with some classical work of the past. As Nobel laureate Paul Nurse informally says "there was life before molecular biology"

\section{The specification of the otic placode and ear induction}

The vertebrate ear develops from the otic vesicle, which in turn is the result of the proliferation, growth and invagination of the otic placode. The otic placode is the first morphological evidence of the specification of the ear territory (Kupffer, 1895) and in some vertebrates, it signifies an irreversible commitment to generate the inner ear. The current view on the developmental origin of the otic placode is that it arises from a preplacodal territory which is competent to generate any placode but not yet specified to develop into any particular one. It is not only after a succession of inductive processes that one portion of the preplacodal ectoderm is specified to become the otic placode. This process is frequently referred to as "otic induction".

Ever since Spemann coined the term 'induction' developmental biologists have struggled with its meaning. Jacobson in his 1966's review in Science (Jacobson, 1966) defined it as: "Embryonic induction is an interaction between one tissue (the inductor) and another responding tissue as a result of which the responding tissue takes a course of differentiation it would not have followed had the interaction not occurred", not very different from that of Slack (1991) and Gurdon (1987). More recently, Wolpert (2002) describes induction as "the process whereby one group of cells signals to another group of cells in the embryo and so affects how they will develop". This interpretation refers to signalling mechanisms linking developmental mechanisms with those of cell biol- ogy, physiology and cancer. But the central point here is that induction is one mechanism by which things happen in the embryo, namely via cells communicating with each other. The process implies to be inductive only when it is not due to the intrinsic, cell autonomous properties of the cells.

The existence of a preplacodal territory, adjacent to the neural plate that has a common potential to generate sense organs and cranial ganglia, was proposed by Jacobson (1966) on the basis of a set of elegant experiments where the ectoderm adjacent to the neural plate was rotated at specific stages of development. The paper by Andrea Streit in this issue (Streit 2007) reviews the work done during the last ten years that deepens our understanding of the molecular mechanisms involved. An initial set of genes (Foxi, $M s x$ and $D / x$ )identify an ectodermal domain from the neural plate and the epidermis. This preplacodal domain is segregated from the neural crest and expresses a specific set of genes. Both the positioning of the preplacodal ectoderm and its capacity to express the specific Six/Eya/Dachcassette seem to require interactions between the presumptive preplacodal domain and the surrounding tissues (Streit, 2007)

How does the preplacodal ectoderm transit from a pluripotent ground state to one in which otic fate is specified? This apparently requires another round of interactions that position and specify the fate of individual placodes (Streit, 2007; Ohyama et al., 2007). This notion of sequential rounds of interactions is classical and was anticipated by Yntema (1950) and Jacobson (1966). The former postulated different sequential rounds of competence and of source activity during otic induction and the latter believed that it was the accumulation of signals from different sources that resulted in placode specification. Crucial here for our modern understanding of this process was the introduction of the concept of specification, as used in fly and Xenopus development in the eighties, to describe the initial stages of commitment to the otic fate, combined with the use of molecular markers to assess it (Gallagher, 1996; Torres \& Giraldez, 1998; Groves \& BronnerFraser, 2000)

We now understand that the specification of the otic placode and the formation of the otic vesicle is a complex process that starts probably very early in the embryo (see above) and that consists of the sequential acquisition by the presumptive otic ectoderm of different states of competence and commitment that result in the specification of the otic placode and the formation of the otic vesicle. This suggests that the common use of the term "otic induction" has in reality very little heuristic value. Indeed, otic induction commonly (and incorrectly) substitutes for otic specification, making the assumption that since otic specification depends on inductive processes the two terms are equivalent. "Otic induction" is also sometimes used to describe only one specific inductive process throughout placode specification, say the expression of an early gene, as a substitute for the whole series of inductive interactions. Classical papers by Harrison, Yntema, Waddington and Jacobson, contributed both to the clarification and to the confusion of this process. The fact that the specification of the otic placode is a result of a series of inductive processes does not mean that specification and induction are interchangeable. Jacobson was particularly concerned about this issue: "But the concept of induction, once separated out and named, has suffered reification. A number of papers imply or refer to "the moment of induction" and attention has prematurely shifted from 
study of the process of embryonic induction to a search for "the inductor substance" (Jacobson, 1966). Careful work during the last few years has disclosed details of otic specification genes and sequences of gene expression patterns (Ohyama et al., 2007) and also the role of specific mesoderm and neural inductive signals like FGFs that are critical for specific transitions from presumptive ectoderm to the otic placode (reviewed by Schimmang, 2007).

\section{Patterning of the ear}

The regional (or axial) polarity needed to develop the membranous labyrinth of the ear has long been recognised as providing the basis for ear function. Classical transplantation experiments showed that rotated otic placodes produce enantiomorphic twins (Harrison 1945; Yntema 1955), which somewhat resemble the symmetric ear of the hagfish. This reversal in polarity will happen along the anteriorposterior axis alone until the dorso-ventral axis becomes fixed somewhat later during otic cup formation. Yntema (1955) suggested that the fixation of polarity in the ear rudiment may be a local expression of a general body polarity. The early patterning of the ear is also set, at least in part, by interactions between the ear and the surrounding tissues, par-
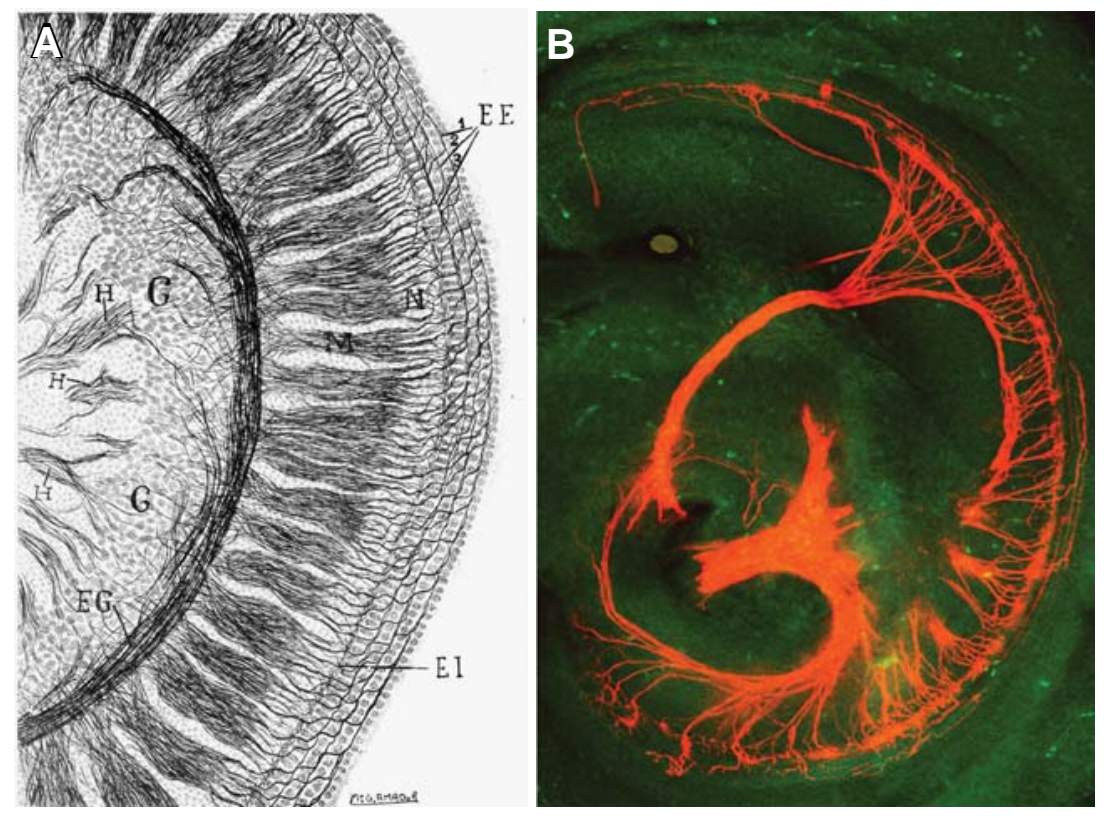

Fig. 1. The inner ear: the cochela. (A) Reconstruction of a 3-day mouse cochlea from three consecutive slices from Ramon y Cajal and Tello y Muñoz (1928). (B) A confocal image using lipophilic dye tracing in a newborn Neurod1 null cochlea. Note the near complete loss of afferents but retention of some radial fibers that spiral along the inner hair cells as well as some fibers reaching the outer hair cells.

ticularly the neural tube. The fist sign of otic regionalisation is that of the establishment of the otic proneural and non-neural fields (Alsina et al., 2004). In the present issue, Abelló and Alsina (2007) review the molecular properties of these two domains and discuss the possible models by which this early specification is set in place and the role of Notch signalling in maintaining initial asymmetries. FGF signals appear to be critical for setting proneural competence in the ear, as there are probably planar interactions between neural competence genes like Sox genes that are expressed in the proneural domain and other patterning genes like Irx, Lmx and Tbx, which are expressed in the posterior, nonneural, domain.

But axial polarity extends to further complexity in the regionalisation of the otic vesicle, when establishing the different domains of the inner ear. The articles by Bok et al., (2007), Whitfield \& Hammond (2007) and Schneider-Maunoury \& Pujades (2007) illustrate very well how inductive processes extend further into the development of the otic vesicle and how important they are in establishing the axial pattern of the ear. Although the axial structure of the ear has been recognised for long, it was not only until recent years that early asymmetries were recognised and mechanisms explored. Perhaps the first recognition of early molecular asymmetries in the ear date from mid-nineties, when $D / x$, SoHo-1, Msx, Otx and Lmx genes were discovered to be restricted to particular areas of the otic placode (see Torres \& Giraldez, 1998 for a summary of those early results). The work done during recent years has beautifully shown that key features of the regional specification of the otic vesicle depend on Wnt, FGF and $\mathrm{SHH}$ signals emanating from the neighbouring neural tube. There is a general consensus that the anterior-posterior axis is fixed before the dorso-ventral and that the otic placode is at some stage equipotent as to the anterior-posterior identity. Bok et al., (2007) suggest that the medial-lateral axis is established earlier than the others, resulting in the expression of Pax2 and Gbx2. Wnt and FGF signals from the mesoderm and hindbrain and $\mathcal{S H H}$ from the notochord and/or ventral neural tube, are critical for axial specification. In a gross approximation, results in mice and chick suggest that FGFs are involved in anteriorposterior (AP) patterning and Wnt and $\mathrm{HH}$ signalling in dorsalventral (DV). However the process itself, -patterning- is concomitant to growth and large morphogenetic movements and also to complex gene interactions, all of which will surely require more elaborated models to be understood. This is illustrated by the analysis of the role of $\mathrm{HH}$ signals in ear patterning. The comparison of the results in mice and zebrafish have given apparently paradoxical effects: the $\mathrm{HH}$ signal affects DV properties in the mouse (and also in chick), but it distinctly modifies the AP patterning in the fish. This is discussed thoroughly by Whitfield \& Hammond (2007) and Schneider-Maunoury \& Pujades (2007), who elaborate on the need of further experiments to elucidate the effects of these signals in patterning and/or cell fate, on the one hand and to analyse how growth and morphogenesis distort the interpretation of the axial polarity in the transition from otic placode to otic vesicle in the different animal species on the other hand

\section{Ear morphogenesis}

One important problem in ear development is that of coupling patterning, morphogenesis and cell fate as distinctly formulated by Donna Fekete (1996). In the present issue, Doris Wu and her colleagues (Bok et al., 2007) review the available knowledge on the molecular basis of ear morphogenesis and how it is coupled to the development of the different ear sensory organs. The 
development of the ear requires the subdivision into the prospective sensory organs, which probably occurs by the subdivision of an early common proneural domain (Cole et al., 2000, Fritzsch et al., 2002 and Neves et al., 2007). This is somehow coupled to the development of the associated non-neural components that need to interact for coordinated development. The expression pattern of Fgf10 and the phenotype of the Fgf10 knockout first suggested a molecular interaction between sensory and non-sensory components (Pauley et al., 2003; Bok etal., 2007). The development of the crista and the formation of the semicircular canals is associated with the activity of dorsal genes such as Gbx2,D/x5and $D / x 6$, which are dependent on Wnt and SHH signaling (Riccomagno et al., 2002, Riccomagno et al., 2005), whereas D/x and Hmx seem to be also critical for canal formation but are not Wnt-dependent. Recent studies from knock out mice have shown also that $\mathrm{HH}$ signaling and Foxg1 are also required for canal formation (Riccomagno et al., 2000; Pauley et al., 2006; Bok et al., 2007 in this issue). As discussed in Bok et al., (2007), the development of the utricle and saccule have a complex and not yet fully understood common origin, that they probably share with the cochleo-vestibular ganglia. Several genes like Hmx and Otx show a macular phenotype and Gata3 seems to be the only one preferentially expressed in the utricle and not in the saccule (Karis et al., 2001).

The morphogenesis and histogenesis of the mammalian cochlea is one of the most interesting problems in ear development. The mammalian cochlea derives from the cochlear duct that then coils (remaining straight in birds) and develops into an exquisitely precise and invariant shape and pattern, both being critical for the function of the organ. The cochlea contains a precise pattern along the logitudinal axis, with a graded variation of mechanical properties of the basilar membrane and of electrical properties of hair cells, that enable the precise tuning of hair cells in a tonotopic pattern. Ping Chen in this issue (Chen, 2007) discusses histogenesis and the interesting "convergent extension hypothesis" of cochlear morphogenesis. Convergent extension is a process of tissue narrowing along one axis with the concomitant extension along a perpendicular axis, the best known example being amphibian gastrulation (Keller, 2002). The process requires coordinated cell behaviors involving cell-cell intercalations and polarization that are organized orthogonally to the longitudinal axis of elongation. Chen discovered that during terminal differentiation, the organ of Corti thins from a four to five cell thickness to a final two cell-layered epithelium that extends along the longitudinal axis (Chen et al., 2002) even if hair cells do not differentiate (Fritzsch et al., 2005). Interestingly, few years ago it was also discovered that the process of convergent extension in vertebrates is regulated by a genetic network that is shared with that of planar cell polarity (PCP). Several mutations reveal that the mammalian PCP pathway regulates the establishment of the characteristic polarity of stereocilia and convergent extension, but they seem not to be mutually dependent. As discussed in the article by Chen (2007) there are various possible models that couple general cues to specific cell behaviors that seem to involve at least the link of Wnt signaling with the intrinsic PCP machinery that drive cell asymmetries. Chen postulates that multiple directional signals converge into the core PCP complexes that are sorted asymmetrically along the medio-lateral axis of the cochlea.

One of the least understood events in ear development is the formation of the perilymphatic spaces (the vestibular and tympanic scalae and non-mammalian functional equivalents) that conduct sound from the oval window to the round window. It seems to be reasonable to assume that the organ of Corti/basilar papilla drives both the thickening of the basilar membrane as well as formation of a cell free space adjacent to it. These spaces seem to form even in Atoh 1 null mice or other mice with highly deviated cochlea development, for example Foxg1 null ears with up to sixteen rows of hair cells (Pauley et al., 2006). Understanding this interaction at a molecular level as much as we understand labyrinth-bone interactions as mediated by FGF9 (Pirvola et al., 2004) requires more information about possible ligands in the organ of Corti as well as possible receptors in the periotic mesenchyme.

\section{Cell fate specification of the neural elements of the ear: the components of the mechanotransducing unit}

The elementary sensory unit of the ear consists of: 1) the hair cells, which are the receptor cells containing the mechanotransducing machinery, 2) the supporting cells that hold 
and space the hair cells in a precise pattern, 3) the otic neurons, which are bipolar, primary afferent neurons, that connect the hair cell with the brain and 4) Schwann cells that enwrap neurons and their axons (except agnathans which have no myelin). They are all neural elements that originate from a proneural domain in the ear, with the exception of most Schwann cells that are of neural crest origin (D'Amico Martel and Noden, 1983; Rubel and Fritzsch, 2002). An immense amount of work has been done on the functional and morphological properties of the ear sensory epithelium, both in the adult and during development and this has been critical for current analysis of human and mouse mutant and transgenic animals. First descriptions on the developing of hair cells and otic neurons can be traced back to the late 19th century as summarized in Retzius (1884) and Ramon y Cajal (1904). The use of immunochemistry in the eighties and in situ hybridization in the nineties allowed more specific descriptions and the collection of a vast amount of information on the timing of development of hair cells and neurons and their synaptic connections in several animal species (see Rubel, 1978: Ruben et al., 1987). But perhaps the first modern attempt to formulate the question of how hair cells are generated was that of Julian Lewis in his paper on "Rules for the production of sensory cells"that anticipated a series of papers that studied the role of delta-notch in cell fate selection of neurons and hair cells (Lewis, 1991; see also Whitefield et al., 1997). The aim of Lewis was to look for a common language for understanding the production of sensory elements in the inner ear, the knowledge about cell differentiation choices in the retina and that on the generation of fly mechanosensory bristles, to take some "lessons from Drosophila". The process was formulated as a sequence of cellular states for which transition rules had to be described (Lewis, 1991). This opened the scientific inquiry to incorporate the framework of fly mechanoreceptor proneuralneurogenic scheme to the understanding of the generation of neurons and hair cells. This resulted in the formulation of a general hypothesis of neurosensory development proposing a conserved nested set of proneural genes as the core of otic neurosensory specification (Fritzsch et al., 2000).

One preliminary but useful scheme of the possible sequence of cell fate decisions from an early multipotent progenitor to the different cell types was also proposed by Donna Fekete in a short review that became a classic (Fekete, 1996). By then, the discovery by Doris Wu that there were genes that foreshadowed the generation of sensory patches (Wu \& Oh, 1966; Oh et al., 1966) and the cloning of the vertebrate homologues of Notch, Deltaand Serrate genes (Henrique, 1995; Myat, 1996) lead to the current view on neuron and hair cell specification: the specification of an epithelial domain with neuro-sensory competence that gives rise to the neurons and hair cells through a mechanism of proneural gene mediated specification, which is enhanced by lateral inhibition (Cole et al., 2000; Alsina et al., 2003, Fritzsch et al., 2006); Sanchez-Calderón et al., 2007; Kelley, 2007).

The concepts of neural prepattern and proneural function have been extensively used in Drosophila to provide a molecular mechanism for the stereotyped development of mechanosensory organs (see Gomez-Skarmeta, 2003). Prepattern genes convey the spatial information that fixes the position of the neurogenic tissue and thus of sensory organs. Subsequent expression of proneural genes would confer on cells the potential to become neural precursors and the ability to differentiate into neural elements and probably to specify its particular subtype (Bertrand et al., 2002). The question of how the proneural domain of the otic vesicle is specified is related to the complementary expression of Soxgenes and pre-pattern genes like $L m x$ and $/ r x$ is discussed by Abello \& Alsina (2007) in this issue. Recent studies also revealed that Sox2in the proneural domain of the otic placode and later on it foreshadows the the sensory organs of the inner ear (Neves et al., 2007). Sox2-deficient mice show hearing and balance impairment, fail to establish a prosensory domain and to differentiate hair or supporting cells (Kiernan et al., 2005). This correlates with the fact that mutations of SOX2 in humans cause sensorineural hearing loss (Hagstrom et al., 2005). These data show that proneural basic Helix-Loop-Helix genes require this prepatterning event to function (Kelley, 2007)

In the late seventies, proneural genes were associated with a gene complex (García-Bellido, 1979) and the genetic and molecular analysis of the achaete-scute complex (ASC) in flies lead to the identification of four genes in the complex, whose vertebrate counterparts were unveiled during the nineties (Ghysen and Dambly-Chaudiere, 2000; Bertrand et al., 2002). A further Drosophila proneural gene, atonal, was isolated later in a PCR-based screen to identify bHLH sequences and the orthologs of this gene subfamily have been shown by loss-of-function analysis to be critical for ear development (see Jarman, 1993; Bermingham et al., 1999; Kim et al., 2001; Ma et al., 1998). It is now clear that Neurog1, NeuroD1 and Atoh1 are at the core of the proneural bHLH function in the ear. They are necessary and sufficient to promote neuronal and hair cell fates, respectively (Fritzsch et al., 2006; Woods et al., 2004) and are reviewed in this issue by Kelley, 2007 and Sanchez-Calderón, et al., 2007). NeuroD1 behaves as a neuronal differentiation gene that acts after Neurog 1 and Atoh 1 is a proneural gene that confers a prosensory cell cluster with competence to develop into hair- and supporting cells. This decision requires lateral inhibition through the Delta-Notch mechanism, which results in the characteristic cellular pattern of ear sensory epithelia (Daudet and Lewis, 2005, Kelley, 2006). Neurog1 is possibly acting at such an early stage of proneural specification so that it is required for both neuron and hair cell specification (Ma et al., 2000, Ma et al., 1998).

The loss of hair cells reported in Neurog1 null mutants was proposed to come about through the clonal relationship of neuronal precursors and hair cell precursors (Fritzsch etal., 2000, Ma et al., 2000). Recent experiments have shown that such clonal relationship exists in chicken (Satoh and Fekete, 2005) and in mice (Koundakjian et al., ARO 2007, Abstract 962). Based on these data it has been hypothesized that at least three proneural populations need to be selected in the otocyst; one population that expresses Neurog1 and gives rise only to neurons, a second population that expresses both Neurog 1 and Sox2and gives rise to neurons and, later, to hair cells/supporting cells and a third population that expresses only Sox 2 and gives rise only to hair cells/supporting cells (Fritzsch et al., 2006). Future work will have to determine with more sophisticated genetic techniques using Cre-Lox approaches the relative size of these three subpopulations.

The idea of a stem cell-like neurosensory precursor population has implications for the attempts to regenerate lost neurosensory elements, including the possible use of adult stem cells isolated from specific areas, which are turned into stem cells through 
molecular engineering (Wernig et al., 2007). While ample data support the notion that Atoh 1 is both necessary and sufficient to differentiate hair cells, this is difficult to reconcile with recent evidence from Atoh1 $+1+;$ Atoh1-/- chimeras where Atoh1-/- hair cells can differentiate (Du et al., 2007) and with the data on topographically correct expression of Atoh1 in the null mutants (Fritzsch et al., 2005). It remains to be seen what other upstream factors drive selective Atoh1 expression and/or hair cell differentiation in the absence of Atoh1. Finally, ectopic expression of Atoh1 induces sensory cells of mixed hair cell-supporting cell phenotypes (Raphael, 2007 in this volume), which suggests that factors other than Atoh1 may be needed to fully de-differentiate supporting cells in a regeneration paradiam. (Liu et al., 2006; Kelley, 2007).

\section{Cell cycle, cell determination and differentiation}

Clonal expansion in the ear is a balance between continued proliferation and differentiation. To achieve this, the ear employs regulation mechanisms well known from other systems, particularly neuronal. The interplay is between various cyclin kinase enhancing and inhibiting factors and their upstream regulators on the one hand and the competing action of so-called activator bHLH genes (Atoh1, Neurog 1) and inhibitor bHIH genes (Hes 1, 5) on the other hand (Kageyama et al., 2005, Kageyama et al., 2007). Combined with a multitude of other factors it will be determined in an iterative fashion whether a postmitotic cell exits the cell cycle for good and, if so decided, will differentiate into a neuron, a hair cell, a supporting cell or general otic epithelium. As with the process of induction, so is the process of cell fate determination something that requires multiple steps, each governed by a different, yet overlapping set of genes. The ultimate decision to continue in the cell cycle or to differentiate is the least understood. Available evidence suggests that free action of E2F proteins, normally inhibited by pocket proteins such as retinoblastoma, will initiate the S-phase entry of the cell cycle. While this can be crudely demonstrated in appropriate null mutants, the biologically relevant molecular interplay in the undisturbed cell will be far more complex as indicated by the work of Segil and Pirvola (Mantela et al., 2005, White et al., 2006). Our current understanding of certain aspects of this process is reviewed here by RochaSanchez (2007) and how this relates to differentiation is discussed by Kelley (2007). Clearly, full understanding of cell cycle regulation with molecular tools to safely start and stop this would be beneficial for any strategy to restore hearing loss.

Likewise, great strides toward a molecular understanding of cell fate determination have been made for neurons and hair cells alike. In neurons it is now clear that the bHLH gene Neurog 1 determines neuronal fate with downstream transcription factors such as NeuroD1 and Pou4f1 (Brn3a) playing various roles in differentiation. In contrast, the sequence of events in the hair cells is not as clear, mostly because the direct demonstration of presence of the bHLH gene Atoh1 in proliferating precursors has not been made (Matei et al., 2005). Thus, Atoh1 appears at the moment to act in the ear of mammals as a cell fate concealing, differentiation factor (Kelley, 2007), since topographically correct upregulation of Atoh1 can be demonstrated in null mutants (Fritzsch et al., 2005). In contrast, zebrafish have two genes, atoh 1a and atoh $1 \mathrm{~b}$ (Millimaki, et al., 2007). atoh1a seems to be associated with prosensory cells, while atohto is associated more directly with hair cell fate specification. Combined these data suggest an unusual degree of variation in hair cell specification processes among vertebrates that needs to be explored at a molecular level. Other genes such as Pou4f3, Gfiland Barlh1are also necessary for full differentiation and maintenance of hair cells. However, it appears that in the ear Atoh 1 is unique in that it is both necessary and sufficient to generate hair cells (Raphael, 2007; this volume). How exactly the early expressed transcription factors tie into the specific hair cell and supporting cell histogenesis is currently unclear and an exhaustive overview of the current state of knowledge is provided in this volume (Kelley, 2007; Richardson, 2007).

\section{Neurons and innervation: connections and survival}

Auditory and vestibular neurons are derived from the otic placode and delaminate to then innervate the sensory organs, connecting them to the central nervous system (D'Amico-Marte and Noden, 1983). In this issue, Sanchez-Calderón et al. (2007) review the network of transcription factors and extrinsic signals that control ear neurogenesis, some of them mentioned above. Little is known however about the process of delamination from the otic cup and vesicle and how innervation proceeds. Neuron production follows a temporal sequence that was established by 3H-Thymidine labelling (Ruben, 1967; D'Amico-Martel, 1982) A long lasting question has been that of whether the neuroblasts leave a track during delamination to direct them back to specific epithelial domains. As discussed by Fekete \& Campero (2007) this does not seem to be a major mechanism to direct innervation. The existence of chemotactic molecules that attract fibers towards the otic epithelium has been shown by co-culture experiments (Ard et al., 1985; Hemond \& Morest, 1992). There are experimental conditions in which ectopically induced sensory patches receive innervation, suggesting that sensory-fated epithelia are able to attract projections from otic neurons. However, the lack of the sensory organs, like the posterior crista in the Fgf10 null mouse, does not prevent the innervation of the corresponding region, suggesting that sensory organs are not necessary for the generation of the topology of neuronal projection (Pauley et al., 2003). Semaphorins, ephrins and slits have a potential role in the establishment of ordered projections from ganglion neurons to the ear. Perturbation of semaphorin signalling, for instance, produces navigation mistakes and neural projections do not arrest at the sensory patches. The lab of Fekete is currently investigating other signals during axon projection and they include the Wnt signalling pathway as a potential mechanism for guidance (Fekete and Campero, 2007).

Results from in vitro experiments and knockout mice indicate that hair cells are relatively autonomous for survival, whereas neurons are strictly dependent on interactions with hair cells. Specifically, otic neurons are known to depend on FGFs, the NGF-related neurotrophins BDNF and NT-3 and Insulin Growth Factor-1 (IGF-1) as major signalling systems for survival. Recent advances on the analysis of the mechanisms of action of those factors are reviewed in depth by Sánchez-Calderón et al., 2007. All neurotrophins bind to p75 NTR, which also interacts with Trk receptors to modulate ligand binding specificity, affinity and function of neurotrophins in certain cell types (Bibel et al., 1999). 
The differential binding of mature and immature proforms of neurotrophins to $\mathrm{p} 75^{\mathrm{NTR}}$ seems to underlie the balance between survival and cell death that is under the control of neurotrophins, although the precise signalling pathways used by $p 75^{\mathrm{NTR}}$ to activate cell death remain unclear and at least involve the generation of ceramides, activation of Jun kinase, caspase cascade and cyclin-dependen kinases (see Sanchez-Calderón et al., 2007). In the normal cochlea, it is almost exclusively hair cells that produce mature BDNF, which activates TrkB receptors on cochlear neurons and favour their survival. Consistently, after aminoglycosideinduced degeneration of hair cells, BDNF availability is reduced, as is TrkB expression. In parallel, p75 NTR expression and c-Jun phosphorylation are augmented in cochlear neurons, suggesting an activation of apoptotic pathways in the absence of neurotrophic support (Tan and Shepherd, 2006). On the other hand, mice carrying a null mutation for the $p 75^{\text {NTR }}$ show progressive hearing loss four months after birth, which is associated with the degeneration of cochlear neurons and hair cell loss at the basal turn of the cochlea (Sato et al., 2006), which is in contrasts with the proposed role of p $75^{\mathrm{NTR}}$ in cell death in the adult cochlea.

IGF-1 has been shown to be critical for early differentiation and survival of otic neurons (Camarero et al., 2001, 2003). The response of target cells to IGF-I is mediated by its high affinity receptor, IGF1R, a transmembrane tyrosine kinase receptor. Binding of IGF-I to IGF1R activates receptor tyrosine kinase activity results in the autophosphorylation of IGF1R and triggers the activation of two main intracellular signalling pathways: the phosphatidylinositol-3 kinase/Akt (PI-3K/Akt) survival pathway; and the Raf/mitogen-activated protein kinase (Raf/MAPK) that activates the proliferation of neuronal cells during development. The activation of the Raf/MAPK cascade is involved in the proliferation of the epithelial inner ear cells and the activation of PI3-kinase/Akt pathway is related to otic cell survival. Insight into the role of IGFs in inner ear cochlear ganglion neurogenesis has come from studies on chick and genetically modified mice (reviewed in Varela-Nieto et al., 2004). Neuronal survival is severely impaired in $/ g f 1-/-$ mice, disclosing the trophic effect of lgf1 in otic neuron development. In summary, there is a great interest in understanding mechanisms and effects of those three families of trophic factors (Fgfs, NTs and IGFs) that are known to maintain neuronal survival during the development of the ear and that are also the basis for understanding and preventing degenerative processes that occur during adult life. While NTs clearly have the lead role in otic neuron survival and also in fibre guidance (Tessarollo et al., 2004), other factors complement and partially substitute for this function (Sánchez-Calderón et al., 2007).

\section{Translating development into cure: molecular models of disease, regeneration and evolution}

Mouse genetics has provided the research community with fantastic tools to address ear development at the organismic level unthinkable even 10 , let alone 20 years ago. Some of the issues discussed above were prompted by studies on mutant and genetically modified mice. Moreover, mouse genetics has also provided a way to identify critical genes related to hearing loss in humans and to deepen insights into the molecular mechanisms associated with hearing impairment. Note that at least sixty per-cent of cases of early hearing impairment are hereditary and most of the known examples are single mutations in a single genes. Karen B. Avraham and co-workers (Friedman et al., 2007) review exhaustively the current work on mouse models as applied to ear development and diseases. Sixty-one protein-coding chromosomal genes and seven tRNA or rRNA coding mitochondrial genes have been linked to hereditary hearing loss in humans. They include genes that code for extracellular matrix components, gap junction and adhesion proteins, ion channels and transporters, other cell surface proteins and receptors, as well as myosins, cytoskeletal proteins, transcription factors and related proteins. Several laboratories are now working to create knockouts and conditional mutants for every gene in the mouse genome (NIH Knockout Mouse Project (KOMP):

http://www.nih.gov/science/models/mouse/knockout/; and European Conditional Mouse Mutagenesis Program (EUCOMM): http://www.eucomm.org/). This vast project will result in many more mouse models for studying human hearing loss and, as a consequence, to identify genes that are critical for ear development. Such information is crucial to define the right strategy to help people born with hereditary hearing loss.

There is now a growing effort to implement knowledge generated in our quest to understand ear development and cell specification toward regeneration studies, essentially investigating some of the same genes and their interactions as have been studied in development. J. Stone and D. Cotanche provide an overview of this work (Stone and Cotanche, 2007). Likewise, the molecular details and techniques developed for the understanding of neuronal development in the ear are now being applied toward strategies to enhance regeneration of sensory neuron processes. For example, researchers are implanting stem cell into the empty modiolus of ears subjected to neuronal-damaging treatments in animal models. Such work clearly shows that translational research of data generated only some years ago is happening at an ever accelerating pace (Edge and MartinezMonedero, 2007). The basic understanding of molecular events of otocyst transformation into the organ of Corti may indeed be the only way to cure the most severe form of hearing loss in which all histologically distinct features of the organ of Corti have been replaced by a simple squamous epithelium, the flat epithelium. Yehoash Raphael (2007) provides on overview on this subject in this volume.

The hair cell is, with respect to its detailed morphology, among the most complex cells in the vertebrate body. This complexity has generated an obstacle to relate the vertebrate hair cell in particular and thus the vertebrate ear in general to cells and organs of deuterostome and protostome invertebrates. In recent years several transcription factors and structural proteins have been found that connect known or suspected invertebrate mechanosensors with those of vertebrates. Clearly, the detailed structure of the hearing organ of the fruitfly, specialized to detect near field particle motion (Eberl and Boekhoff-Falk, 2007), has not much in common with the mammalian organ of Corti, an organ that detects sound pressure differences. And yet, despite the disparate morphology and adaptation to perceive a different physical aspect of sound, loss of the rare myosin VII renders both flies and man deaf (Todi et al., 2005). In addition, both fly and mammalian mechanosensory cells require atonal/Atoh 1 for their development (Fritzsch et al., 2000) thus implying molecular continuity despite morphological dissimilarities. Fritzsch and col- 
leagues propose in this volume, in analogy to the eye evolution, that an ancestral set of genes has been modified to produce divergent morphologies, rendering all mechanosensory cells homologous at this molecular level. Important here is that as with other developing systems, the molecular insights gained from invertebrate model systems can, within limits, be extrapolated to understand vertebrate diseases. It is most unfortunate that the mechanosensory channel is, unlike the photon transducing proteins (Arendt et al., 2004), still unknown and thus it remains speculative as to how this developmental transcription factor cassette is tied into this very basic process of any mechanosensory cell.

Epilogue: In 1987 a document was published that described the discussions of a symposium organized by Bob Ruben (Cremers et al., 1987). The main thrust of this symposium was to provide a snapshot of the state of the art in genetics, developmental biology, histopathology and plasticity of sensorineural hearing loss and to suggest strategies toward cure and prevention. Obviously, the progress made since then is dramatic as judging from the many more pages detailing issues raised only as questions 20 years ago. It is not only the volume of detail that has increased to a previously unimaginable molecular level, but it is significant that this progress now increasingly lends itself to translational research using cellular and molecular therapy. We do hope that this special volume will serve not only as a snapshot of our current state of the art, both with respect to insights and lack thereof, but will encourage others to continue the work and provide lasting help to all congenital deaf or postnataly deafened people. Performing a linear extrapolation of the dramatic progress over the last 20 years in understanding of molecular biology of cell cycle regulation and differentiation of sensory neurons and hair cells makes us optimistic that the next 20 years will provide the tools necessary to jump-start proliferation and initiate differentiation of lost neurons and hair cells in the ear.

\section{Acknowledgements}

We wish to thank Donna M. Fekete and Domingos Henrique for comments. The work was supported by grants BFU2005-03045, from MEC, from NIH (RO1 DC005590; BF) and LB692 (BF).

\section{References}

ABELLO, G and ALSINA, B. (2007) Establishment of a proneural field in the inner ear. Int J Dev Bio/51: 483-493. DOI: 10.1387/ijdb.072343ga

ADAM, J., MYAT, A., LE ROUX, I., EDDISON, M., HENRIQUE, D., ISH-HOROWICZ, D. and LEWIS, J. (1998). Cell fate choices and the expression of Notch, Delta and Serrate homologues in the chick inner ear: parallels with Drosophila senseorgan development. Development 125: 4645-54.

ALSINA, B., GIRALDEZ, F. and VARELA-NIETO, I. (2003). Growth factors and early development of otic neurons: interactions between intrinsic and extrinsic signals. Curr Top Dev Bio/57: 177-206.

ALSINA, B., ABELLO G, ULLOA E, HENRIQUE D, PUJADES C, GIRALDEZ, F. (2004) FGF signaling is required for determination of otic neuroblasts in the chick embryo. Dev Biol. 267:119-34.

ARENDT, D., TESSMAR-RAIBLE, K., SNYMAN, H., DORRESTEIJN, A.W. and WITTBRODT, J. (2004). Ciliary photoreceptors with a vertebrate-type opsin in an invertebrate brain. Science 306: 869-71.

ARD M.D., MOREST, D.K. and HAUGER, S.H. (1985) Trophic interactions between the cochleovestibular ganglion of the chick embryo and its synaptic targets in culture Neuroscience. 16:151-70.

BERMINGHAM, N.A., HASSAN, B.A., PRICE, S.D., VOLLRATH, M.A., BEN-ARIE,
N., EATOCK, R.A., BELLEN, H.J., LYSAKOWSKI, A. and ZOGHBI, H.Y. (1999). Math1: an essential gene for the generation of inner ear hair cells. Science 284 1837-41.

BERTRAND, N., CASTRO, D.S. and GUILLEMOT, F. (2002). Proneural genes and the specification of neural cell types. Nat Rev Neurosci3: 517-30.

BIBEL, M., HOPPE, E. and BARDE, Y.A. (1999). Biochemical and functional interactions between the neurotrophin receptors trk and p75NTR. EMBO J18: 616-22.

BOK, J., CHANG, W. and WU, D.K. (2007) Patterning and morphogenesis of the vertebrate inner ear. Int J Dev Bio/51: 521-533. DOI: 10.1387/ijdb.072381jb

BOYER, L.A., LEE, T.I., COLE, M.F., JOHNSTONE, S.E., LEVINE, S.S., ZUCKER J.P., GUENTHER, M.G., KUMAR, R.M., MURRAY, H.L., JENNER, R.G. et al. (2005). Core transcriptional regulatory circuitry in human embryonic stem cells. Cel/122: 947-56.

CAMARERO, G., AVENDAÑO, C., FERNANDEZ-MORENO, C., VILLAR, A., CONTRERAS, J., DE PABLO, F., PICHEL, J.G. and VARELA-NIETO, I. (2001). Delayed inner ear maturation and neuronal loss in postnatal lgf-1-deficient mice. JNeurosci21: 7630-41

CAMARERO, G., LEON, Y., GOROSPE, I., DE PABLO, F., ALSINA, B., GIRALDEZ, F. and VARELA-NIETO, I. (2003). Insulin-like growth factor 1 is required for survival of transit-amplifying neuroblasts and differentiation of otic neurons. Dev Bio/262: 242-53.

CHEN, P., JOHNSON, J.E., ZOGHBI, H.Y. and SEGIL, N. (2002). The role of Math1 in inner ear development: Uncoupling the establishment of the sensory primordium from hair cell fate determination. Development 129: 2495-2505

CHISAKA, O. and CAPECCHI, M.R. (1991) Regionally restricted developmental defects resulting from targeted disruption of the mouse homeobox gene hox1.5. Nature 350: 473-9.

COLE, L.K., LE ROUX, I., NUNES, F., LAUFER, E., LEWIS, J. and WU, D.K. (2000). Sensory organ generation in the chicken inner ear: contributions of bone morphogenetic protein 4, serrate1 and lunatic fringe. J Comp Neuro/424: 509 20.

CREMERS, C.W.R.J., GRAHAM, J., PARVING, A. and RUBEN, R.J. (1988) Biology of sensorineural hearing loss in children. Report of symposium held in Holte, Denmark, 14-17 June, 1987. Int. J. Pediatric Otorhynolayrngology 15: 1 15

D'AMICO-MARTEL, A. (1982) Temporal patterns of neurogenesis in avian cranial sensory and autonomic ganglia. Am J Anat. 163:351-372.

D'AMICO-MARTEL, A. and NODEN, D.M. (1983) Contributions of placodal and neural crest cells to avian cranial peripheral ganglia. Am J Anat. 166:445-68.

DAUDET, N. and LEWIS, J. (2005). Two contrasting roles for Notch activity in chick inner ear development: specification of prosensory patches and lateral inhibition of hair-cell differentiation. Development 132: 541-51.

DU, X., JENSEN, P., GOLDOWITZ, D. and HAMRE, K.M. (2007). Wild-type cells rescue genotypically Math1-null hair cells in the inner ears of chimeric mice. Dev Bio/305: 430-8.

EBERL, D.F. and BOEKHOFF-FALK, G. (2007) Development of Johnston's organ in Drosophila. Int J Dev Bio/51: 679-687. DOI: 10.1387/ijdb.072364de

FEKETE, D.M. (1996). Cell fate specification in the inner ear. Curr Opin Neurobiol 6: 533-41.

FEKETE, D.M. and WU, D.K. (2002) Revisiting cell fate specification in the inner ear. Curr Opin Neurobiol.12:35-42.

FEKETE, D.M. and CAMPERO, A.M. (2007) Axon guidance in the inner ear. Int J Dev Bio/51: 549-556. DOI: 10.1387/ijdb.072341df

FRIEDMAN, L.M., DROR, A.A.and AVRAHAM, K.B. (2007) Mouse models to study inner ear development and hereditary hearing loss. Int J Dev Bio/51: 609-631. DOI: $10.1387 / \mathrm{ijdb} .072365 \mathrm{If}$

FRITZSCH, B., BARALD, K. and LOMAX, M. (1998). Early embryology of the vertebrate ear. In Springer Handbook of Auditory Research. Vol XII. Development of the Auditory System.. (ed. RUBEL, E. W.POPPER, A. N. and FAY, R. R.). Springer Verlag, New York, pp.80-145

FRITZSCH, B., BEISEL, K.W. and BERMINGHAM, N.A. (2000). Developmental evolutionary biology of the vertebrate ear: conserving mechanoelectric transduction and developmental pathways in diverging morphologies. Neuroreport 11: R35-44. 
FRITZSCH, B., BEISEL, K.W., JONES, K., FARINAS, I., MAKLAD, A., LEE, J. and REICHARDT, L.F. (2002). Development and evolution of inner ear sensory epithelia and their innervation. JNeurobio/53: 143-56.

FRITZSCH, B., MATEI, V.A., NICHOLS, D.H., BERMINGHAM, N., JONES, K., BEISEL, K.W. and WANG, V.Y. (2005). Atoh1 null mice show directed afferent fiber growth to undifferentiated ear sensory epithelia followed by incomplete fiber retention. Dev Dyn 233: 570-83.

FRITZSCH, B., BEISEL, K.W. and HANSEN, L.A. (2006). The molecular basis of neurosensory cell formation in ear development: a blueprint for hair cell and sensory neuron regeneration? Bioessays 28: 1181-93.

FRITZSCH, B., BEISEL, K., PAULEY, S. and SOUKUP, G. (2007) Molecular evolution of the vertebrate mechanosensory cell and ear. Int J Dev Bio/51: 663678. DOI: $10.1387 / \mathrm{ijdb} .072367 \mathrm{bf}$

GALLAGHER, B.C, HENRY, JJ and GRAINGER, R.M. (1996). Inductive processes leading to inner ear formation during Xenopus development. Dev Biol. 10:95107

GARCIA-BELLIDO, A. Genetic analysis of the achaete-scute system of Drosophila melanogaster. Genetics 91, 491-520 (1979).

GHYSEN, A. and DAMBLY-CHAUDIERE, C. (2000). A genetic programme for neuronal connectivity. Trends Genet 16: 221-6.

GÓMEZ-SKARMETA, J.L., CAMPUZANO, S. and MODOLELL, J. (2003) Half a century of neural prepatterning: the story of a few bristles and many genes. Nat Rev Neurosci. 2003 Jul;4(7):587-98.

GOROSPE, I., SANCHEZ-GALIANO, S., CANON, S., CAMARERO, G., CONTRERAS, J., CEDIEL, R. et al. (2004). Trophic effects of insulin-like growth factor-I (IGF-I) in the inner ear. Hear Res 196: 19-25.

GRAHAM V, KHUDYAKOV J, ELLIS P, PEVNY L (2003) SOX2 functions to maintain neural progenitor identity. Neuron 39:749-65.

GROVES, A.K. and Bronner-Fraser, M. (2000) Competence, specification and commitment in otic placode induction. Development 127:3489-99.

GURDON, J.B. (1987) Embryonic induction-molecular prospects. Development 99:285-306.

HAGSTROM, S.A., PAUER, G.J., REID, J., SIMPSON, E., CROWE, S., MAUMENEE, I.H.,AND TRABOULSI, E.I. (2005) SOX2 mutation causes anophthalmia, hearing loss and brain anomalies. Am J Med Genet $A$. 138:95-8.

HARRISON (1945) Relations of symmetry in the developing embryo. Trans. Conn. Acad. Arts Sci. USA 22: 238-247

HEMOND, S.G. and MOREST, D.K. (1992) Tropic effects of otic epithelium on cochleo-vestibular ganglion fiber growth in vitro. Anat Rec. 232:273-84.

HENRIQUE, D,. Adam,J., Myat, A., Chitnis, A., Lewis, J. and, Ish-Horowicz D (1995) Expression of a Delta homologue in prospective neurons in the chick. Nature 29;375:787-90.

JACOB, F. (1947) Quoted by Gilbert (1997) Developmental Biology. Ch2, page 47 Sinauer Associates Inc. Publishers, Sunderland, Massachusetts.

JACOB, F. (1976) The Logic of Life by François Jacob, English edition by Princeton University Press 1993

JACOBSON, A.G. (1966) Inductive processes in embryonic development. Science 152: $25-34$

JAENISCH, R., HOCHEDLINGER, K., BLELLOCH, R., YAMADA, Y., BALDWIN, K. and EGGAN, K. (2004) Nuclear cloning, epigenetic reprogramming and cellular differentiation. Cold Spring Harb Symp Quant Biol. 69:19-27.

KAGEYAMA, R., OHTSUKA, T., HATAKEYAMA, J. and OHSAWA, R. (2005). Roles of bHLH genes in neural stem cell differentiation. Exp Cel/ Res 306: 343 8.

KAGEYAMA, R., OHTSUKA, T. and KOBAYASHI, T. (2007). The Hes gene family: repressors and oscillators that orchestrate embryogenesis. Development 134: 1243-51.

KARIS, A., PATA, I., VAN DOORNINCK, J.H., GROSVELD, F., DE ZEEUW, C.I., DE CAPRONA, D. and FRITZSCH, B. (2001). Transcription factor GATA-3 alters pathway selection of olivocochlear neurons and affects morphogenesis of the ear. J Comp Neuro/429: 615-30.

KELLER, R. (2002) Shaping the vertebrate body plan by polarized embryonic cell movements. Science. 298:1950-4.

KELLEY, M.W. (2007). Cellular commitment and differentiation in the organ of Corti.
Int J Dev Bio/51: 571-583. DOI: 10.1387/ijdb.072388mk

KELLY, M. and CHEN, P. (2007) Shaping the mammalian auditory sensory organ by the planar cell polarity pathway. Int J Dev Bio/51: 535-547. DOI: 10.1387/ ijdb.072344mk

KIERNAN AE, PELLING AL, LEUNG KK, TANG AS, BELL DM, TEASE C, LOVELLBADGE R, STEEL KP, CHEAH KS. (2005). Sox2 is required for sensory organ development in the mammalian inner ear. Nature 434: 1031-1035.

KIM, W.Y., FRITZSCH, B., SERLS, A., BAKEL, L.A., HUANG, E.J., REICHARDT, L.F., BARTH, D.S. and LEE, J.E. (2001). NeuroD-null mice are deaf due to a severe loss of the inner ear sensory neurons during development. Development 128: 417-26.

KOUNDAKJIAN, E., APPLER, J. and GOODRICH, L. (2007) Transgenic Mouse: a Tool to Fate Map Cells in the Mouse Inner Ear. ARO2007, Abstract 962

LEWIS, J. (1991) Rules for the production of sensory cells. In: Regeneration of vertebrate sensory receptor cells. Ciba Found Symp. 160:25-39; discussion 4053. Wiley, Chicester,

LIU J.J., SHIN, J.H., HYRC, K.L., LIU, S., LEI, D., HOLLEY, M.C. and BAO, J. (2006) Stem cell therapy for hearing loss: Math1overexpression in VOT-E36 cells. Otol Neurotol. 27:414-421.

MA, Q., CHEN, Z., DEL BARCO BARRANTES, I., DE LA POMPA, J.L. and ANDERSON, D.J. (1998). Neurogenin1 is essential for the determination of neuronal precursors for proximal cranial sensory ganglia. Neuron 20: 469-82.

MA, Q., ANDERSON, D.J. and FRITZSCH, B. (2000). Neurogenin 1 null mutant ears develop fewer, morphologically normal hair cells in smaller sensory epithelia devoid of innervation. J Assoc Res Otolaryngo/1: 129-43.

MANTELA, J., JIANG, Z., YLIKOSKI, J., FRITZSCH, B., ZACKSENHAUS, E. and PIRVOLA, U. (2005). The retinoblastoma gene pathway regulates the postmitotic state of hair cells of the mouse inner ear. Development 132: 2377-88.

MARTINEZ-MONEDERO, R. and EDGE, A.S.B. (2007) Stem cells for the replacement of inner ear neurons and hair cells. Int $J$ Dev Bio/ 51: 655-661. DOI: 10.1387/ijdb.072372rm

MCGINNIS W, HART CP, GEHRING WJ and RUDDLE FH. (1984) Molecular cloning and chromosome mapping of a mouse DNA sequence homologous to homeotic genes of Drosophila. Cel/38(3):675-80

MILLIMAKI, B.B., SWEET, E.M., DHASON, M.S. and RILEY, B.B. (2007) Zebrafish Atoh1 genes: classic proneural activity in the inner ear and regulation by Fgf and Notch. Development 134: 295-305.)

MYAT A, HENRIQUE D, ISH-HOROWICZ D. and LEWIS J. (1996) A chick homologue of Serrate and its relationship with Notch and Delta homologues during central neurogenesis. Dev Biol. 174:233-47.

NAYAK, G.D., RATNAYAKA, H.S.K., GOODYEAR, R.J. and RICHARDSON, G.P. (2007) Development of the hair bundle and mechanotransduction. Int J Dev Biol 51: 597-608. DOI: 10.1387/ijdb.072392gn

NEVES, J. KAMAID, A., ALSINA, B. and GIRALDEZ, F. (2007) Differential expression of Sox2 and Sox3 in neuronal and sensory progenitors of the developing inner ear of the chick. J Comp Neurol. 503:487-500.

OHYAMA, T., GROVES, A.K. and MARTIN, K. (2007) The first steps towards hearing: mechanisms of otic placode induction. Int J Dev Bio/51: 463-472. DOI: 10.1387/ijdb.072320to

PAULEY, S., LAI, E. and FRITZSCH, B. (2006). Foxg1 is required for morphogenesis and histogenesis of the mammalian inner ear. Dev Dyn 235: 2470-82.

PAULEY, S., WRIGHT, T.J., PIRVOLA, U., ORNITZ, D., BEISEL, K. and FRITZSCH, B. (2003). Expression and function of FGF10 in mammalian inner ear development. Dev Dyn 227: 203-15.

PIRVOLA, U., ZHANG, X., MANTELA, J., ORNITZ, D.M. and YLIKOSKI, J. (2004) Fgf9 signaling regulates inner ear morphogenesis through epithelial-mesenchymal interactions. Dev Bio/273: 350-60.

RAMÓN Y CAJAL, S (1904) trad: Texture of the Nervous System of Man and the Vertebrates Cajal, S. R.; Pasik, Pedro; Pasik, Tauba ISBN: 3211832025 Editorial: Springer Verlag Wien, 2002

RAMÓN Y CAJAL, S. and TELLO Y MUÑOZ, J. F. (1928). Elementos de Histología Normal y de Técnica micrográfica. Madrid: Tipografía artística. 10 Ed., 1940

RAPHAEL, Y., KIM, Y.H., OSUMI, Y. and IZUMIKAWA, M. (2007) Non-sensory cells in the deafened organ of Corti: approaches for repair. Int J Dev Bio/51: 649654. DOI: $10.1387 / \mathrm{ijdb} .072370 \mathrm{yr}$ 
RETZIUS (1884). Das Gehörorgan der Wirbeltiere: II. Das Gehörorgan der Amnioten. Stockholm: Samson und Wallin.

REX, M., ORME, A., UWANOGHO, D., TOINTON, K., WIGMORE, P.M., SHARPE. P.T. and SCOTTING P.J. (1997) Dynamic expression of chicken Sox2 and Sox3 genes in ectoderm induced to form neural tissue. Dev Dyn. 209:323-32

RICCOMAGNO, M.M., MARTINU, L., MULHEISEN, M., WU, D.K. and EPSTEIN, D.J. (2002). Specification of the mammalian cochlea is dependent on Sonic hedgehog. Genes Dev 16: 2365-78.

RICCOMAGNO, M.M., TAKADA, S. and EPSTEIN, D.J. (2005). Wnt-dependent regulation of inner ear morphogenesis is balanced by the opposing and supporting roles of Shh. Genes Dev 19: 1612-23.

ROCHA-SANCHEZ, S.M.S. and BEISEL, K.W. (2007) Pocket proteins and cell cycle regulation in inner ear development. Int J Dev Bio/51: 585-595. DOI: $10.1387 /$ ijdb.072387sr

ROMAND, R. (1992) Development of Auditory and Vestibular systems 2. Romand, R. ed. Elsevier, Oxford, 1992

RUBEL, EW (1984) Ontogeny of auditory system function. Annu Rev Physiol. 46: 213-29.

RUBEL, E.W. and FRITZSCH, B. (2002). Auditory system development: primary auditory neurons and their targets. Annu Rev Neurosci25: 51-101.

SAIKI, R.K., Scharf, S., Faloona, F., Mullis, K.B., Horn, G.T., Erlich, H.A. and Arnheim, N. (1985) Enzymatic amplification of beta-globin genomic sequences and restriction site analysis for diagnosis of sickle cell anemia. Science230:13501354.

SÁNCHEZ-CALDERÓN, H., MILO, M., LEÓN, Y. and VARELA-NIETO, I. (2007) A network of growth and transcription factors controls neuronal differentation and survival in the developing ear. Int J Dev Biol 51: 557-570. DOI: 10.1387/ ijdb.072373hs

SATO, T., DOI, K., TANIGUCHI, M., YAMASHITA, T., KUBO, T. and TOHYAMA, M. (2006). Progressive hearing loss in mice carrying a mutation in the p75 gene. Brain Res 1091: 224-34.

SATOH, T. and FEKETE, D.M. (2005). Clonal analysis of the relationships between mechanosensory cells and the neurons that innervate them in the chicken ear. Development 132: 1687-97.

SCHIMMANG, T. (2007) Expression and functions of FGF ligands during early otic development. Int J Dev Bio/51: 473-481. DOI: 10.1387/ijdb.072334ts

SCHNEIDER-MAUNOURY, S. and PUJADES, C. (2007) Hindbrain signals in otic regionalization: walk on the wild side. Int J Dev Bio/51: 495-506. DOI: 10.1387/ ijdb.072345ss

SLACK, J.M.W. (1991) From Egg to Embryo 2 ${ }^{\text {nd }}$. ed Cambridge University Press. Cambridge, U.K.
STONE, J.S. and COTANCHE, D.A. Hair cell regeneration in the avian auditory epithelium (2007) Int J Dev Bio/51: 633-647. DOI: 10.1387/ijdb.072408js

STREIT, A. (2007) The preplacodal region: an ectodermal domain with multipotential progenitors that contribute to sense organs and cranial sensory ganglia. Int $J$ Dev Bio/51: 447-461. DOI: 10.1387/ijdb.072327as

TAN, J. and SHEPHERD, R.K. (2006). Aminoglycoside-induced degeneration of adult spiral ganglion neurons involves differential modulation of tyrosine kinase $B$ and p75 neurotrophin receptor signaling. Am J Patho/169: 528-43

TESSAROLLO, L., COPPOLA, V. and FRITZSCH, B. (2004). NT-3 replacement with brain-derived neurotrophic factor redirects vestibular nerve fibers to the cochlea. J Neurosci24: 2575-84.

TODI, S.V., FRANKE, J.D., KIEHART, D.P. and EBERL, D.F. (2005). Myosin VIIA defects, which underlie the Usher 1B syndrome in humans, lead to deafness in Drosophila. Curr Bio/15: 862-8.

TORRES, M and GIRALDEZ, F.(1998).The development of the vertebrate inner ear. Mech Dev71: 5-21

VON KUPFFER, C. (1895). Studien zur vergleichenden Entwicklungsgeschichte des Kopfes der Kraniolen, Vol 3. Die Entwicklung der Kopfnerven van Ammocoetes planeri. Lehmann. Munich, pp. 80

WHITE, P.M., DOETZLHOFER, A., LEE, Y.S., GROVES, A.K. and SEGIL, N. (2006). Mammalian cochlear supporting cells can divide and trans-differentiate into hair cells. Nature 441: 984-7.

WHITEFIELD, T., HADDON, C. and LEWIS, J. (1997) Intercellular signals and cellfate choices in the developing inner ear: origins of global and of fine-grained pattern. Semin Cell Dev Biol. 1997 Jun;8(3):239-247

WHITFIELD, T.T. and HAMMOND, K.L. (2007) Axial patterning in the vertebrate inner ear. Int J Dev Bio/51: 507-520. DOI: 10.1387/ijdb.072380tw

WOLPERT, L. (2002) Principles of Deveopment, Oxford Univesity Press, Oxford, U.K.

WOODS, C., MONTCOUQUIOL, M. and KELLEY, M.W. (2004). Math1 regulates development of the sensory epithelium in the mammalian cochlea. NatNeurosci 7: $1310-8$.

WU, D.K. and OH, S.H.(1996) Sensory organ generation in the chick inner ear. $J$ Neurosci. 1996 Oct 15;16(20):6454-62

YNTEMA (1933) Experiments on the determination of the ear ectoderm in the embryo of Amblyostoma Punctatum. J. Exp. Zool. 65: 317-357

YNTEMA (1955) An analysis of induction of the ear from foreign ectoderm in the salamander embryo. J. Exp. Zool. 113: 211-244.

Published Online: 31st August 2007 


\section{Related, previously published Int. J. Dev. Biol. articles}

See our Special Issue Ear Development edited by Fernando Giraldez and Bernd Fritzsch at: http://www.ijdb.ehu.es/web/contents.php?vol=51\&issue=6-7

Fate of cranial neural crest cells during craniofacial development in endothelin-A receptor-deficient mice Makoto Abe, Louis-Bruno Ruest and David E. Clouthier Int. J. Dev. Biol. (2007) 51: 97-105

Genetic control of dorsoventral patterning and neuroblast specification in the Drosophila Central Nervous System

Guoyan Zhao, Scott R. Wheeler and James B. Skeath

Int. J. Dev. Biol. (2007) 51: 107-115

Where do we stand now? - mouse early embryo patterning meeting in Freiburg, Germany (2005)

Takashi Hiiragi, Vernadeth B. Alarcon, Toshihiko Fujimori, Sophie Louvet-Vallée, Marek Maleszewski, Yusuke Marikawa, Bernard Maro and Davor Solter

Int. J. Dev. Biol. (2006) 50: 581-588

Principles of branch formation and branch patterning in Hydrozoa

Stefan Berking

Int. J. Dev. Biol. (2006) 50: 123-134

The fate of larval flagellated cells during metamorphosis of the sponge Halisarca dujardini

Yulia I. Mukhina, Vadim V. Kumeiko, Olga I. Podgornaya and Sofia M. Efremova

Int. J. Dev. Biol. (2006) 50: 533-541

Head-tail patterning of the vertebrate embryo: one, two or many unresolved problems?

Claudio D. Stern, Jeroen Charité, Jacqueline Deschamps, Denis Duboule, Anthony J. Durston, Marie Kmita, JeanFrançois Nicolas, Isabel Palmeirim, Jim C. Smith and Lewis Wolpert

Int. J. Dev. Biol. (2006) 50: 3-15

Antero-posterior patterning of the vertebrate digestive tract: 40 years after Nicole Le Douarin's PhD thesis Anne Grapin-Botton

Int. J. Dev. Biol. (2005) 49: 335-347

Single-cell transcriptional profiles and spatial patterning of the mammalian olfactory epithelium Ian Tietjen, Jason Rihel and Catherine G. Dulac

Int. J. Dev. Biol. (2005) 49: 201-207

Transdifferentiation of corneal epithelium: evidence for a linkage between the segregation of epidermal stem cells and the induction of hair follicles during embryogenesis.

David J Pearton, Corinne Ferraris and Danielle Dhouailly

Int. J. Dev. Biol. (2004) 48: 197-201

Hair follicle differentiation and regulation.

George E Rogers

Int. J. Dev. Biol. (2004) 48: 163-170 